\title{
A Tale of Two Languages. \\ Latin, the Vernacular, and Leonardo Bruni's Civic Humanism
}

\author{
HESTER SCHADEE
}

This article reconstructs the views of Leonardo Bruni concerning the different natures, historical trajectories, and domains of Latin and the Florentine vernacular. It argues that his encomia of Florentine culture are careful to distinguish the two, and indeed that this distinction holds the key to reconciling the seemingly contradictory positions regarding Dante, Petrarch, and Boccaccio espoused in his Dialogues for Pier Paolo Vergerio. Bruni's concept of the Latin language, moreover, explains why he believed that humanists were required to restore it to its Ciceronian glory. If Latin regained the functions it had had in Cicero's day, this would exclude the Ciompi and the lower guilds from Florentine politics, and thus refashion Florence in the image of the Roman Republic both linguistically and politically. The article therefore salvages some of Hans Baron's civic humanism, in that it shows Bruni - Baron's archetypical civic humanist - to advocate self-government by the Latinate elites.

\section{Introduction}

Ever since the publication of Hans Baron's Crisis of the Early Italian Renaissance, his concept of civic humanism has been paradigmatic in the study of early Quattrocento literary culture, its influence only cemented by copious - and often justified - criticism. ${ }^{1}$ According to Baron's classical thesis, civic humanism was born in 1402, when Florence escaped the tyrannical clutches of the Milanese Duke Gian Galeazzo Visconti, who died while keeping the city-state under siege. Baron perceived this struggle as a clash between opposing ideologies: an autocratic strongman setting out to crush a free republic. Florence's unexpected survival as a self-governing commune, he argued, occasioned a

* I am grateful to the editors and anonymous reviewers of this journal for their detailed and extremely helpful feedback.

${ }^{1}$ H. Baron, The Crisis of the Early Italian Renaissance. Civic Humanism and Republican Liberty in an Age of Classicism and Tyranny (Princeton, NJ, 1966²). For an overview of its reception, see J. Hankins, "The 'Baron Thesis' after Forty Years and Some Recent Studies of Leonardo Bruni”, Journal of the History of Ideas 56.2 (1995), 309-338; and R. Witt, "The Crisis After Forty Years", The American Historical Review 101.1 (1996), 110-118. 
new pride in her political system and liberty. The city's intellectual avant-garde, previously absorbed in an a-political classicism, turned their energies, and knowledge of classical authors, to the service of the state, thus becoming civic humanists. This expressed itself in their identification of the Republic as the heyday of Rome, and of the Empire as a period of decline, since single rule is incompatible with virtue and cultural brilliance. It also brought about a revaluation of Florence's indigenous literary culture, especially the three crowns of the Trecento: Dante (ca. 1265-1321), Petrarch (1304-1374), and Boccaccio (1313-1375). The pivotal figure and key exhibit in Baron's account was Leonardo Bruni (ca. 1370-1444), himself a native of Arezzo.

Baron's opponents have since exposed the dubious dating of crucial texts that allowed him to reach these conclusions; demonstrated the long history of supposedly new ideas; and disputed the sincerity of civic humanists who, they argued, were better viewed as professional rhetoricians. ${ }^{2}$ Last but not least, they have denied the egalitarianism of civic humanist republicanism. ${ }^{3}$ What has not been in doubt, however, is the leading role played by Baron's hero Bruni in turning civic humanist discourse into a hall-mark of the Florentine intellectual and political

${ }^{2}$ For the disputes about dating, now settled, see Hankins 1995 (as in n. 1), 315, n. 12, for bibliography; for the pre-history of civic humanism's tenets, see Q. Skinner, "The Vocabulary of Renaissance Republicanism: A Cultural longue-durée?", in A. Brown (ed.), Language and Images of Renaissance Italy (Oxford, 1995), 87-110; N. Rubinstein, "Political Theories in the Renaissance", in A. Chastel (ed.), The Renaissance. Essays in Interpretation (London, 1982), 153-200; G. Tanturli, "Continuità dell'umanesimo civile da Brunetto Latini a Leonardo Bruni", in C. Leonardi (ed.), Gli umanesimi medievali (Firenze, 1998), 735-780; and J. Blythe, “'Civic Humanism' and Medieval Political Thought", in J. Hankins (ed.), Renaissance Civic Humanism. Reappraisals and Reflections (Cambridge, MA, 2000), 30-74; for debates about its sincerity, see P. Herde, "Politik und Rhetorik in Florenz am Vorabend der Renaissance", Archiv für Kulturgeschichte 47 (1965), 141-220; J. Seigel, “'Civic Humanism' or Ciceronian Rhetoric? The Culture of Petrarch and Bruni", Past \& Present 34 (1966), 3-48; to which Baron responded with "Leonardo Bruni: 'Professional Rhetorician' or 'Civic Humanist'?", Past \& Present 36 (1967), 21-37; and J. Hankins, "Rhetoric, History, and Ideology. The Civic Panegyrics of Leonardo Bruni", in Id. 2000 (as in this note), 143-178; Witt 1996 (as in n. 1) offers a qualified defence of civic humanists' sincerity.

${ }^{3}$ N. Najemy, Corporatism and Consensus in Florentine Electoral Politics 1280-1400 (Chapel Hill, NC, 1982), 301-317; and Id., "Civic Humanism and Florentine Politics", in Hankins 2000 (as in n. 2), 75-104; M. Jurdjevic, "Civic Humanism and the Rise of the Medici", Renaissance Quarterly 52.4 (1999), 994-1020; P. Gilli, "Le discours politique florentin à la Renaissance: autour de 1' "humanisme civique'", in J. Boutier, S. Landi, O. Rouchon (ed.), Florence et la Toscane XIVe-XIXe siècles. Les dynamiques d'un État italien (Rennes, 2004), 323-343. 
elites. Indeed, interpretations of Bruni's Dialogues for Pier Paolo Vergerio (Dialogi ad Petrum Histrum) - a crucial text in these debates - have increasingly emphasised the self-fashioning nature of this complex work, whose first book vehemently attacks the standing of the Florentine tre corone (three crowns), while the second sings their praises. Whereas Baron believed the two books to reflect Bruni's different attitudes before and after the momentous events of 1402, modern scholars have stressed the work's fundamental unity, and argued that it really is an exploration of the preconditions for literary study; the relation of the present to the past; and above all of the ongoing process - evidenced by the text itself - of humanism's cultural renewal. ${ }^{4}$

While these observations are correct, they do not adequately explain why Bruni put in writing apparently contradictory views about Florence's fourteenth-century authors in the two books of his Dialogues. More generally, the ramifications of what for Bruni doubtlessly was the most important instance of cultural decline under the Empire have not been systematically considered. As a result, the potential of humanism to effectively undo it, and so, from Bruni's perspective, to contribute to the public life of Florence - the extent to which it was a truly civic humanism, if not in the Baronian sense - has remained hidden from view. This article tackles these distinct yet connected matters, and proposes that the missing link between them lies in Bruni's theory of language, Latin as well as the vernacular. While both languages thrived in Florence, according to Bruni they had different historical trajectories, and different innate possibilities and domains. The revival of the more exalted one - Latin - could and probably should have an impact well beyond the scholar's study, to wit on the practical politics of the Florentine commune.

Bruni's understanding of historical, including linguistic, change is reviewed in the next section of this article, which also explains why the Latin language was a special case. The third section examines the im-

\footnotetext{
${ }^{4}$ Especially D. Quint, "Humanism and Modernity. A Reconsideration of Bruni's Dialogues", Renaissance Quarterly 38.3 (1985), 423-445; L. Boje Mortensen, "Leonardo Bruni's Dialogus. A Ciceronian Debate on the Literary Culture of Florence", Classica e Mediaevalia 27 (1986), 259-302; R. Fubini, "All'uscita dalla scolastica medievale. Salutati, Bruni, e i Dialogi ad Petrum Histrum", Archivio storico italiano 150 (1992), 1065-1103; and C. Quillen, "The Uses of the Past in Quattrocento Florence. A Reading of Leonardo Bruni's Dialogues", Journal of the History of Ideas 71.3 (2010), 363-385, who includes a useful overview of the historiography.
} 
plications of these findings for the different positions of Latin and Italian in Bruni's writings, especially in the Dialogues. It demonstrates that the contradictions in this text are resolved by distinguishing Latin from the vernacular: in other words, under the guise of a recantation, the work's principal tenets remain intact. The fourth and final section seeks to reconstruct the functions of a restored classical Latin by connecting Bruni's statements concerning language and public life, and situating these in contemporary political practice. This suggests - proof cannot be had since, perhaps prudently, Bruni did not spell out the logical conclusion - how the linguistic change propagated by the early humanists might alter the governance of Florence. In this argument, which reverses Baron's presentation of classicism as a-political, it is through its very Ciceronianism that humanism can make a civic contribution. ${ }^{5}$ This renders Bruni a revolutionary republican - if, to the modern eye, of a reactionary persuasion.

Before embarking on this analysis, it will be useful briefly to locate the works to be examined in the context of their author's career. ${ }^{6}$ The first of these is the Laudation on the City of Florence (Laudatio Florentinae urbis, 1404), which Bruni wrote towards the end of his first sojourn in Florence, where he had moved for the sake of his studies. Within a few years, the Dialogues for Pier Paolo Vergerio (ca. 14071408) followed, set in his old Florentine circle under the aegis of the city's chancellor Coluccio Salutati (1331-1406). At this time, Bruni was employed as apostolic secretary in Rome, but he returned to Florence to serve as chancellor in 1410, only to resign by mid-1411. In 1413 he once more entered Florence in the retinue of Pope John XXIII, and two years later, when that pope's deposition at the Council of Constance (and subsequent excision from the papal numbering) left Bruni unemployed, he returned to Florence for good. He immediately started writing the History of the Florentine People (Historiae Florentini populi), which earned him several benefits from the Signoria, including the grant of Florentine citizenship in 1416, the year in which the first book was

\footnotetext{
${ }^{5}$ Coming from a different angle, this argument thus lends support to the identification of civic humanism as an oligarchic tool by John Najemy 1982, and Id. 2000 (both as in n. 3).

${ }^{6}$ For Bruni's life, see C. Vasoli, "Bruni, Leonardo, detto Leonardo Aretino", in Dizionario biografico degli italiani, vol. 14 (Roma, 1972); G. Griffiths, J. Hankins, D. Thompson (ed.), The Humanism of Leonardo Bruni. Selected Texts (Binghamton, NY New York, NY, 1987), 15-46; L. Martines, The Social World of the Florentine Humanists 1390-1460 (Princeton, NJ, 1963), 117-123, 165-176.
} 
published (the last was finished 26 years later). In 1427, Bruni was appointed chancellor for the second time, and also delivered a Funeral Oration for Nanni Strozzi (Oratio in funere Iohannis Strozzae), which was effectively a second panegyric on Florence. In 1435, when Florence played host to the papal curia, Bruni took part in a conversation about the nature of the Latin language, writing down his position soon after. The next year, he began to compose laudatory biographies of Dante, Petrarch, and Boccaccio in the vernacular, but never completed the last. Bruni died in office in 1444.

These writings of Bruni's, thus, span more than three decades, and moreover a regime change, as Cosimo de' Medici's return from exile in 1434 spelled the inception of Medici hegemony. Although Bruni counted members of the ousted Albizzi faction among his friends, he remained professionally unaffected, indeed thrived. Furthermore, there is no indication of any change in outlook in his writings regarding the issues that will be examined here. Nor should this cause surprise, given that oligarchic governance (albeit with different supporters and personnel) was practised by the Medici as well as by the Albizzi, and moreover - on which more in what follows - always constituted Bruni's political ideal. ${ }^{7}$

\section{Decline and Rise of the Literary Republic}

As is well known, Bruni maintained that people, and therefore states, flourish when the path to greatness lies open, but grow stunted when overshadowed by others. Indeed, the first book of Bruni's History of the Florentine People is organised around this principle. Prior to Rome's dominance, Etruria had held the greatest wealth, power and reputation, but this Etruscan virtue was lost with the ascendancy of Rome. ${ }^{8}$ Likewise, when Florence had been founded, "the nearness of Rome in her grandeur

\footnotetext{
${ }^{7}$ R. Zaccaria, "Il Bruni cancelliere e le istituzioni della Repubblica", in P. Viti (ed.), Leonardo Bruni. Cancelliere della Repubblica di Firenze (Firenze, 1990), 97-116; G. Ianziti, "Leonardo Bruni, the Medici, and the Florentine Histories", in Id., Writing History in Renaissance Italy. Leonardo Bruni and the Uses of the Past (Cambridge, MA, 2012), 186-203, with review of the literature at 186-187.

${ }^{8}$ J. Hankins (ed., tr.), Leonardo Bruni, History of the Florentine People, 3 vol. (Cambridge, MA, 2001-2007) [henceforth Bruni, History], 1.13, 1.36. Translations of Bruni's History follow Hankins with minor alterations; all other translations in this article are my own.
} 
limited Florentia's rise to power," whereas after the fall of Rome, "the other cities immediately began to raise their heads and flourish."

As Bruni's narrative continues, however, it becomes clear that the revival was not quite so immediate, and in fact proceeded "little by little". First, the Italian peoples were oppressed by centuries of barbarian rule. But with the re-founded Empire far away in Germany, the Italian cities "began to pay heed to liberty" and "acknowledge the Empire's authority nominally rather than in practice." 10 Then two factions arose in the Tuscan cities, one "devoted to the imperial name" - the Ghibellines and one "who more embraced the liberty of peoples." 11 With the victory of the latter - the Guelfs - in Florence, the city's emancipation from the ghost of Rome was complete. So the first book of Bruni's History concludes; the second begins by showing how, liberty regained, the Florentines immediately march out to found their own empire. ${ }^{12}$

But what, then, caused the fall of Rome, which at no point was overshadowed by an even greater power? The reason, in Bruni's narrative, is a version of the same principle, now acted out within the state. When Rome came under single rule, the career paths open to the republican aristocracy were closed off, and thereby the incentives for selfbetterment disappeared. ${ }^{13}$ By transitioning from Republic to Empire, Rome thus stunted itself. This difference in psychology attributed to citizens and subjects, respectively, is evident also in the Funeral Oration for Nanni Strozzi, where Bruni ties ambition specifically to inhabitants of republics: "When the means and opportunity for attaining honours are offered among a free people it is amazing how far that goes towards spurring the qualities of the citizens." 14 That the principate stifled the

9 Ibid., 1.10-11: "Crescere tamen civitatis potentiam ac maiorem in modum attolli, Romanae magnitudinis vicinitas prohibebat"; "confestim reliquae civitates efferre capita et florere coeperunt."

${ }^{10}$ Ibid., 1.74: "Civitates Italiae paulatim ad libertatem respicere ac imperium verbo magis quam facto confiteri coeperunt." For Bruni's dating of this process, see also A. Mazzocco, "Decline and Rebirth in Bruni and Biondo", in P. Brezzi, M. de Panizza Lorch (ed.), Umanesimo a Roma nel Quattrocento (New York, NY - Roma, 1984), 249-266.

${ }^{11}$ Bruni, History, 1.81: "Imperatorio nomini"; "qui libertatem populorum magis complectebantur."

12 Ibid., 1.81-3, 2.1-3.

${ }^{13}$ Ibid., 1.38.

${ }^{14}$ S. Daub (ed.), Leonardo Brunis Rede auf Nanni Strozzi. Einleitung, Edition und Kommentar (Stuttgart, 1996) [henceforth Bruni, Nanni Strozzi], ch. 23: "Atque hec honorum adipiscendorum facultas potestasque libero populo proposita mirabile quantum valet ad ingenia civium excitanda." 
Roman people's qualities is pithily proclaimed in the Laudation on the City of Florence, on the authority of Tacitus: "After the state had come into the power of one man, those splendid minds (as Cornelius says) disappeared." 15

Yet this malaise was not only due to the psychology of subjects, but also to the pathology of autocrats, as Bruni describes in the Histories. First of all, there was the carnage of successive civil wars, in which many outstanding people lost their lives. The blame for this Bruni squarely attributes to Caesar and Augustus, while Nero's reign witnessed such slaughter of the upper-classes that, "when he died, the artisan class was beginning to fear for its life, as the Roman nobility had been eliminated."16 Why all this? Bruni explains the self-destruction as follows: the emperors "feared all men in whom they recognised something of excellence, hated whom they feared, and put whom they hated to the sword." 17 In the Funeral Oration, he moreover formulates the general principle that kings are more suspicious of good than of bad men, and always fearful of the virtues of others. ${ }^{18}$ For these reasons - the psychology of subjects, and the pathology of autocrats - Bruni's History summarises that "one cannot deny that the fall of the Roman Empire began then, when the name of Caesar, like some kind of plague, came to loom over the city." 19 Caesar, thus, was personally responsible for slaughtering Roman luminaries, and metonymically stood for the regime

15 Bruni, History, 1.38: "Declinationem autem Romani imperii ab eo fere tempore ponendam reor quo, amissa libertate, imperatoribus servire Roma incepit;" Leonardo Bruni, Laudatio Florentine urbis, in L. Bernard-Pradelle (ed., tr.), Leonardo Bruni Aretino, Histoire, eloquence et poésie à Florence au début du Quattrocento (Genève, 2008), 204301 [henceforth Bruni, Laudatio], ch. 41: "Nam posteaquam res publica in unius potestatem deducta est, preclara illa ingenia (ut inquit Cornelius) abiere;" Tac. Hist. 1.1: "Postquam bellatum apud Actium atque omnem potentiam ad unum conferri pacis interfuit, magna illa ingenia cessere." See K. Schellhase, Tacitus in Renaissance Political Thought (Chicago, IL, 1976), 17-25 for the availability and use of Tacitus' Histories in Florence.

16 Bruni, History, 1.38: "Ut verissime a quoquam sit dictum tunc Neronem periisse, cum cerdonibus timendum esse coeperat; absumpta videlicet Romana nobilitate."

17 Ibid., 1.38: "Ut timerent cunctos in quibus excellens aliquid conspicarentur et quos timerent odissent et quos odissent ferro trucidarent."

18 Bruni, Nanni Strozzi, ch. 22: "Regibus, inquit historicus, boni quam mali suspectiores sunt semperque his aliena virtus formidolosa est." The source of this sentiment is Sallust, Cat. 7.2, and ultimately Xenophon, Hiero, esp. 3.1-6, which Bruni translated in 1401-1403 and on which see B. Maxson, "Kings and Tyrants. Leonardo Bruni's translation of Xenophon's Hiero", Renaissance Studies 24.2 (2010), 188-206.

19 Bruni, History, 1.38: "Negare non poterit tunc Romanum imperium ruere coepisse, cum primo caesareum nomen, tamquam clades aliqua, civitati incubuit." 
that supplanted the Republic and squandered Rome's excellence. This is also how Caesar features in the Laudation, notwithstanding his acknowledged personal qualities ("Oh Caesar, how blatantly your crimes overturned the City of Rome! [... but] although you had many and great vices, still they were overshadowed by many and great virtues"), and in the Dialogues' reprisal of that passage, which will be discussed below. ${ }^{20}$

Clearly, these associations are operative when the Ghibellines are labelled "the Caesarian faction", as happens in the Dialogues. ${ }^{21}$ The connection is explained in the Laudation, where Bruni's argument on the topic is threefold. First, he maintains that Florence was founded from Rome when she was in her prime, namely before "the Caesars, Antonii, Tiberii, and Neros - plagues and ruins of the Republic - carried off her liberty." 22 Second, that owing to this foundation, the Florentines "always delight most of all in liberty, and are very hostile to tyrants." ${ }^{23}$ Third, that this explains their Guelf allegiance, since they hate "whatever name or trace remains" of those who seized the Empire and subverted the Republic. ${ }^{24}$ Guelfism, then, is the natural continuation of Roman republicanism, and both are defined against the oppression of liberty by Caesar and the emperors. This renders it fitting that in Bruni's History, the emancipation of Florence from the Holy Roman Empire should usher in her own period of bloom. Yet while that text - true to the subject matter of historia - treats this ascent primarily in terms of military prowess, Bruni viewed the Florentines' renewed virtue as encompassing all domains of citizen activity: in this respect Florence is no different from

${ }^{20}$ Bruni, Laudatio, ch. 40: "O Cai Cesar, quam plane tua facinora Romanam urbem evertere! Sed comprimam ipse me. Sunt enim qui Lucanum, doctissimum et sapientissimum hominem, vera de te scripsisse permoleste ferant. Nec fortasse carent ratione: etsi enim multa ac magna in te vitia erant, multis tamen ac magnis virtutibus obumbrabantur."

${ }^{21}$ S. Baldassarri (ed.), Leonardo Bruni, Dialogi ad Petrum Paulum Histrum (Firenze, 1994) [henceforth Bruni, Dialogi], ch. 57: "Verum illud maxime in ea oratione me delectavit: quod studia partium nostrarum et a praeclaro initio exorta et merito atque optimo iure $\mathrm{ab}$ hac civitate probas suscepta. Caesaream vero factionem, quae huic nostrae inimica est, referendo eorum scelera et deplorando libertatem populi Romani in summam invidiam adducis."

22 Bruni, Laudatio, ch. 34: "Nondum Cesares, Antonii, Tiberii, Nerones, pestes atque exitia rei publice, libertatem sustulerant."

23 Ibid., ch. 34: "Ut Florentini homines maxime omnium libertate gaudeant et tyrannorum valde sint inimici."

24 Ibid., ch. 34: "Si quod illorum vel nomen vel vestigium adhuc superest id hec res publica dedignatur et odit;" ibid., ch. 35: "Non sunt nova in Florentino populo hec partium studia, nec nuper, ut quidem arbitrantur, incepit. [...] Nec si alio atque alio nomine diversis temporibus he partes appellate sunt, ideo tamen fuere." 
Rome. The cultural, and specifically linguistic, dimension of this revival is discussed in Bruni's biographies of Dante and Petrarch. In these, he examines the decline and rise of the Latin language, which closely follows the geopolitical developments outlined so far.

In the Life of Petrarch (Vita del Petrarca), Bruni's most extensive exposition on this subject, he recounts how the perfection of Latin increased "little by little, [and] at the time of Cicero reached its highest peak." At that point, however, "just like the city of Rome was destroyed by the emperors, wicked tyrants, so studies and the Latin letters suffered similar ruin and reduction, so that at last hardly anyone could be found who knew Latin with any sense of style." 25 Then the Goths and Lombards followed, "barbarous and foreign nations, who in fact almost extinguished all knowledge of letters, as is clear from the acts drawn up and produced in those times, than which nothing more base, rough and coarse can be found." However, when the Lombards were driven out, and Italy regained her liberty, the Tuscan cities recovered a little, and "began to polish their coarse style somewhat."26

At this point, however, something unexpected happens - or rather, does not happen. According to Bruni, with the waxing of the cities, there was no truly analogous increase in Latin skills: the language remained known to few, and it was known badly, without real judgement of style. This is despite the fact that vernacular poetry flourished at this time. As he elaborates in his Life of Dante (Vita di Dante), the authors of the era, while skilled in vernacular verse, did not know how to write Latin, even though they were learned in the scholastic manner of the monks. ${ }^{27}$ Why did Latin not naturally re-establish itself in the growing Tuscan com-

${ }^{25}$ Bruni, Vite di Dante e del Petrarca, in Bernard-Pradelle 2008 (as in n. 15), 866-915 [henceforth Bruni, Vite], ch. 41: "Salendo a poco a poco sua perfetione, nel tempo di Tullio nel più alto colmo divenne;" ibid., ch. 42: "La città di Roma annichilata dalli imperadori, perversi tiranni, così gli studi et le lettere latine ricevetteno simile ruina et diminutione, intanto che allo extremo quasi non si trovava chi lettere latine con alcuna gentilezza sapesse."

${ }^{26}$ Ibid., ch. 42: "Et sopravvennero in Italia Goti et Longobardi, nationi barbare et strane, e quali affatto quasi spensero quasi ogni cognitione di lettere, come appare nelli strumenti in quelli tempi rogati et fatti, de' quali niente potrebbe essere più materiale cosa, né più grossa, et rozza;" ibid., ch. 43: "cominciarono a riaversi et a dare opera alli studi et alquanto limare il grosso stilo."

${ }^{27}$ Ibid., ch. 33: "Di gentilezza di dire in prosa o in versi latini niente intesero gl'huomini di quel secolo, ma furono rozzi et grossi et senza peritia di lettere, dotti, niente di meno, in queste discipline, al modo fratesco e scolastico." 
munes, which proved fertile soil for the developing vernacular? Arguably, the disparity conforms to Bruni's view of classical Latin.

The residence of Pope Eugenius IV in Florence (1434-1438) provided the occasion for a debate between Bruni and Biondo Flavio (13921463), employed in the papal curia, on the nature of classical Latin, and its relation to the Italian vernaculars. Both men, but particularly Biondo, found adherents among other humanists, some present, others joining the conversation in writing. A turning point in the history of linguistics, the ensuing controversy has generated a large scholarship; here, the focus will be Bruni's and Biondo's opening positions. ${ }^{28}$ Biondo argued that after the fall of the Roman Empire, a fusion of Latin with the languages of the new rulers - Goths and Vandals, a proposition he later revised to the Lombards - gave birth to an early form of Italian. Rome, therefore, had known only one language, namely Latin. Bruni's view, which is preserved in an epistle addressed to Biondo in 1435 - the year before his biographies of Dante and Petrarch - was the opposite. He maintained that there had always been two languages, in antiquity as in the present. Modern Italian was, if not identical to, at least a development from an equivalent vernacular which was spoken on the streets of ancient Rome. Classical Latin by contrast, then as now, was not a natural

${ }^{28}$ The texts of Bruni and his interlocutors are available in M. Tavoni, Latino, grammatica e volgare. Storia di una questione umanistica (Padova, 1984). Bruni's "An vulgus et literati eodem modo locuti sint" [henceforth Bruni, "An vulgus"] is at 216-221; translated into English in Griffiths, Hankins, Thompson 1987 (as in n. 6), 229-234. Biondo's text is critically edited in F. Delle Donne (ed.), Blondus Flavius, De verbis Romanae locutionis (Roma, 2008); his and Bruni's, with small variations and extensive commentary, in G. Marcellino, G. Ammannati (ed., tr.), Il latino e il 'volgare' nell'antica Roma. Biondo Flavio, Leonardo Bruni e la disputa umanistica sulla lingua degli antichi Romani (Pisa, 2015), which also comprises an Italian translation. A. Raffarin (ed., tr.), Débats humanistes sur la langue parlée dans l'Antiquité (Paris, 2015) follows previous editions but includes a translation in French. Additionally, the contents of the debate are discussed in A. Mazzocco, Linguistic Theories in Dante and the Humanists. Studies of Language in Late Medieval and Early Renaissance Italy (Leiden - Köln - New York, NY, 1993), and R. Fubini, "Consciousness of the Latin Language among Humanists: Did the Romans Speak Latin?", in Id., Humanism and Secularization. From Petrarch to Valla, tr. M. King (Durham, NC - London, 2003), 9-42. Building on Fubini, Christopher Celenza has argued that the historicisation of the Latin language in this controversy spurred the awareness of historical change and instability that characterises early sixteenth-century Florentine humanism: "Why Florence? Pocock, Civic Humanism, and the Debate over the Latin Language", in N. Baker, B. Maxson (ed.), After Civic Humanism. Learning and Politics in Renaissance Italy (Toronto, 2015), 49-70. 
language that children pick up as they start to speak, but an artificial language, whose grammar had to be mastered through education. ${ }^{29}$

Against the new insights of Biondo, Bruni's position was traditional, and in some respects identical to that expressed by Dante in On Vernacular Speech (De vulgari eloquentia, ca. 1302-1305) and The Banquet (Convivio, ca. 1304-1307). ${ }^{30}$ In the former treatise, Dante had argued that all vernacular languages were prone to develop and diversify, rendering them mutually incomprehensible: this he saw as divine retribution for man's insolence in building the Tower of Babel. Prior to this catastrophe, all people had spoken the language first voiced by Adam in Eden, which was universal and unchanging. In order to compensate for its loss, mankind then created artificial languages governed by strict and fixed rules, which Dante termed gramatica. For the Romans, this gramatica was Latin. ${ }^{31}$ While Dante deemed vernacular speech "more noble", being the basis for grammatical language and the natural tongue for all, and furthermore professed his love for it in The Banquet, he nevertheless noted as Latin's advantage that it "is eternal and not corruptible, and the vernacular not stable and corruptible" - the latter will therefore be unrecognisable in a thousand years. ${ }^{32}$ Although Bruni dispensed with this biblical aetiology, he likewise considered Latin a human invention coterminous with grammar, which he believed the vernacular languages wholly lacked. ${ }^{33}$ If Bruni's ideas about language were thus backward-looking, his Life of Petrarch nonetheless demonstrates the influence of Biondo. While in his earlier writings, Bruni had emphasised the institution of Empire as a cultural turning point, he now also identified the barbarian invasions as causes of linguistic change. But whereas Biondo saw the birth of Italian, Bruni's focus was on the decline of Latin.

${ }^{29}$ Bruni, “An vulgus", 216-217.

30 For Dante's linguistic views, see Mazzocco 1993 (as in n. 28), 24-29; on Dante and Bruni, ibid., 30-38.

${ }^{31}$ S. Botterill (ed., tr.), Dante Alighieri, De vulgari eloquentia (Cambridge, 1996), 1.1.3.

32 "Harum quoque duarum nobilior est vulgaris" (ibid., 1.1.4); "lo latino è perpetuo e non corruttibile, e lo volgare è non stabile e corruttibile", F. Brambilla Ageno (ed.), Dante Alighieri, Convivio (Firenze, 1995), 1.5.7, 1.5.9-10.

33 Indeed, the wish to refute this notion may well have driven Leon Battista Alberti (1404-1472), another curial secretary, to compose his Grammar of the Tuscan Language in 1437, two years after Biondo's and Bruni's debate: see M. Tavoni, "The 15th-Century Controversy about the Language Spoken by the Romans. An Inquiry into Italian Humanist Concepts of 'Latin', 'Grammar' and 'Vernacular'”, in P. Ramat, H.-J. Niederehe, E. Koerner (ed.), The History of Linguistics in Italy (Amsterdam, 1986), 23-50, at 25-30. 
In his letter to Biondo, Bruni does not explain why educated Romans used Latin rather than Rome's vernacular speech, but it is likely that his reasoning was the same as Dante's. Counter-intuitively to the modern mind, Latin qualified for certain types of discourse because it was not natural. Its artificial grammar provided stability as well as clarity and precision; furthermore, Latin had a defined vocabulary, and was free from the dialectical variations. These features rendered it suitable when precise, enduring, and universal communication between educated men was required. This line of thinking also means that one should not suppose that Bruni disapproved of the vernacular. Just like Dante himself had done, Bruni maintained, in his Life of the poet, that the vernacular could be perfect in its own way. ${ }^{34}$ But it had no claims to the particular endowments of Latin.

If Latin, being an artificial language, could not be learned in the wet nurse's lap, as Bruni stated in his letter to Biondo, it likewise did not grow organically alongside the vernacular in the blossoming city states. ${ }^{35}$ To learn it again, a teacher was needed, and the example of ancient authorities. The first man to understand this, according to Bruni, was Petrarch, who paved the way - even if he did not yet attain perfection - for a revival of classical Latin. He achieved this through recovering, studying and imitating the man whose works embody the high point of Latinity, namely Cicero. ${ }^{36}$ In actual fact, Petrarch was less of a Ciceronian than Bruni makes him out to be. Petrarch saw antiquity - and with it Latinity - as extending to the fall of Rome in the fifth century. Later, Salutati had included the Church fathers among the models of good Latin. ${ }^{37}$ The tenet that "the Latin language never flourished more than in Cicero's time," as it is succinctly put in the Dialogues, was therefore not the established opinion; moreover the position is problem-

34 For which see J. Hankins, "Humanism in the Vernacular. The Case of Leonardo Bruni", in C. Celenza, K. Gouwens (ed.), Humanism and Creativity in the Renaissance. Essays in Honor of Ronald Witt (Leiden, 2006), 11-29, esp. at 14; and A. Rizzi, "Leonardo Bruni and the Shimmering Facets of Languages in Early Quattrocento Florence", I Tatti Studies in the Italian Renaissance 16.1/2 (2013), 243-256, esp. at 252.

35 Bruni, "An vulgus", 218-220.

${ }^{36}$ Bruni, Vite, ch. 44: "Posto che in lui perfetto non fusse, pure da sé vide et aperse la via a questa perfetione, ritrovando l'opere di Tullio et quelle gustando et intendendo, adactandosi, quanto poté et seppe, a quella elegantissima et perfectissima facondia."

37 T. Mommsen, "Petrarch's Conception of the 'Dark Ages"”, Speculum 17.2 (1942), 226-242; R. Donovan, "Salutati's Opinion of the Non-Italian Latin Writers of the Middle Ages", Studies in the Renaissance 14 (1967), 185-201. 
atic, in that it casts the Augustan golden age of Latin poetry (Virgil, Horace, Ovid) and historiography (Livy) as the inception of decline. ${ }^{38}$ Yet Bruni's reasons are quite clear, and determined by the framework of causation set forth in the History. As he explains in the Life of Petrarch:

One can say that letters and the study of the Latin language went hand in hand with the state of the Roman Republic, since until the age of Cicero there was an increase; but then, after the Roman people had lost their liberty under the rule of the emperors, who did not even stop at killing and ruining men of high esteem, the good state of the city of Rome perished together with the condition of studies and letters. ${ }^{39}$

The murderous habits of the emperors, combined with the malaise of Empire, require that Latin reached its peak beforehand.

Thus it was Guelfism, which Bruni cast as continuation of Roman republicanism and cause of Florence's renewed bloom, that also created the preconditions for the rebirth of both Italian and Latin. But before this latter, artificial, language could thrive, its rules had to be rediscovered. The catalyst in this respect was Petrarch, who took Cicero for his model. Going back to the halcyon days of the Republic, he began to recover the language as it had once flourished in a free state. That it would flourish again in Florence is demonstrated by Bruni's own writings; and indeed he comments on the city's prowess in this respect more than once. ${ }^{40}$ In Bruni's presentation, therefore, humanists were the ones who delivered on the promise of the times. As midwives of Ciceronian Latin, they reversed the linguistic damage inflicted by the Caesars.

38 Bruni, Dialogi, ch. 23: "Scimus enim nunquam magis quam Ciceronis tempore Latinam linguam floruisse." For the pioneering Ciceronianism of Bruni's circle, and especially of the Dialogues' dedicatee Vergerio, see R. Witt, In the Footsteps of the Ancients. The Origins of Humanism from Lovati to Bruni (Boston, MA - Leiden, 2000), 443-494.

39 Bruni, Vite, ch. 41: "Et puossi dire che le lettere et gli studii della lingua Latina andassero parimente co' lo stato della repubblica di Roma, però che per infino alla età di Tullio ebbe accrescimento; dipoi, perduta la libertà del popolo romano per la signoria delli imperadori, i quali non restarono mai d'uccidere et di disfare gl'huomini di pregio, insieme col buono stato della città di Roma perì la buona dispositione delli studi et delle lettere."

40 As will be shown in the next section. 


\section{A Tale of Two Languages}

It must be recognised that, while Bruni acknowledges the vernacular in a number of texts, and wrote for example his biographies of the three crowns of Florence in the vernacular, his linguistic and literary interest was predominantly in Latin. ${ }^{41}$ Even though Florence, as Bruni claims, excels in both, it is Latin that he privileges over the other. To grasp this, it is necessary to consider a point of Bruni's own Latin usage.

At the very end of the Laudation, in a short but strategically placed paragraph - it is the last one before Bruni's brief peroration and closing prayer to John the Baptist - the humanist discusses Florence's literary endowments. His remarks are brief - a mere seven sentences - and this may have served to obscure the fact that Bruni discusses not one but two literary cultures:

For what shall I say about the sweetness of their speech and elegance of their words? Indeed in this matter the city without question ranks first. Only she in the whole of Italy is deemed to have the purest and clearest speech. Hence all men who want to speak well and correctly take their example from this city. For this city hosts men who in this popular and common mode of speaking show all others to be like children. But even letters - not indeed those that are paid for and base, but those which are worthiest of free men, those which always flourish among every sovereign people - thrive the most in this one city. ${ }^{42}$

Bruni's exact meaning is not immediately obvious, owing to his use of the term "letters" (littere): in consequence, the standard English translation reads as if he distinguishes everyday speech from literature ${ }^{43}$ This

${ }^{41}$ See Hankins 2006 (as in n. 34) for a discussion of Bruni's vernacular output.

${ }^{42}$ Bruni, Laudatio, ch. 91: "Nam quid ego de orationis suavitate et verborum elegantia loquar? In qua quidem re sine controversia superat. Sola enim hec in tota Italia civitas purissimo ac nitidissimo sermoni uti existimatur. Itaque omnes qui bene atque emendate loqui volunt, ex hac una urbe sumunt exemplum. Habet enim hec civitas homines qui in hoc populari atque communi genere dicendi ceteros omnes infantes ostenderint. Littere autem ipse, non mercennarie ille quidem neque sordide, sed que maxime sunt liberis hominibus digne, que in omni principe populo semper floruerunt, in hac una urbe plurimum vigent."

${ }^{43}$ B. Kohl (tr.), Leonardo Bruni, Panegyric on the City of Florence, in B. Kohl, R. Witt (tr.) The Earthly Republic. Italian Humanists on Government and Society (Manchester, 1978), 135-175, at 174: "Now what shall I say of the persuasiveness of their speech and the elegance of their discourse? Indeed, in this category the Florentines are the unquestioned leaders. All of Italy believes that this city alone possesses the clearest and purest speech. All who wish to speak well and correctly follow the example of the 
is not the case. Humanists commonly use the word litterae to signify Latin, in this regard following the Latin grammarians. These had identified the littera as the smallest element of language that could be distinguished (a phoneme, in modern terminology) and as such be written down: this, they held, separated human speech from the indistinct noises of nature ${ }^{44}$ The fact that it was possible to write Latin thus rendered it lettered, even when it remained spoken. In the passage above, it is quite clear that the sermo (speech) that Bruni calls the purest language of Italy and a model for all, and circumscribes as popular and common mode of speaking, must be the Florentine vernacular. The following sentence then presents a strong contrast: "But even letters." If the transcription of the spoken word in writing were at stake - that is to say, if these letters referred to literature in the vernacular - that contrast would be inexplicable, since it was precisely through the writings of Dante, Petrarch, and Boccaccio that Florentine was the model for a pan-Italic vernacular. ${ }^{45}$ When, however, it is understood that "letters" signifies Latin, the nonsequitur suddenly makes sense: Bruni contends that not only X, but also $Y$. Moreover, specifying these letters as being not for money, but worthy of free (liber) men, the Latin with which Bruni is concerned is not that used for documents or contracts, but rather the medium of the liberal arts (artes liberales)..$^{46}$ In other words, humanist Latin.

That Bruni's littere in the Laudation are Latin is confirmed by an almost identical passage in his Funeral Oration for Nanni Strozzi:

Florentine manner of speech, for this city possesses men who are so expert in their use of the common vernacular language that all others seem like children compared to them. The study of literature - and I don't mean simply mercantile and vile writings but that which is especially worthy of free men - which always flourishes among every great people, grows in this city in full vigour."

${ }^{44}$ Tavoni 1986 (as in n. 33), 32.

${ }^{45}$ Rizzi 2013 (as in n. 34), 250-252, argues that Bruni, here and in the debate with Biondo, defines the vernacular as essentially oral, but this is gainsaid not only by the circulation of the three crowns' vernacular works in writing, but also by Bruni's own production in that language from the 1420s onwards, for which see Hankins 2006 (as in n. 34). Indeed, Rizzi's own examples demonstrate that terms such as "oris elegantia" were applied to writing as well as speech.

46 It may be noted parenthetically that the Italian word lettera includes among its historical significations Latin: S. Battaglia (ed.), Grande dizionario della lingua italiana, vol. 8 (Torino, 1973), s.v. "lettera", 19. It is used with this meaning in contrast to the vernacular for instance by Pier Candido Decembrio, when he comments on his translations "di littera in vulgare", H. Schadee, "The First Vernacular Caesar. Pier Candido Decembrio's Translation for Inigo d'Avalos, with Editions and Translations of Both Prologues", Viator 46.1 (2015), 277-304, at 298. 
For what will I say now about letters and studies? Indeed in this one matter by common consent the greatest and most brilliant supremacy is attributed to our city. And I don't speak or think of those letters that are vulgar and written for pay - although our people excel in those too - but of those more polished and more divine studies, whose excellence is deemed greater and whose glory everlasting and immortal. For who can, either in our own time or before, name a poet who is not a Florentine? Who called this expertise in speaking which was already completely lost back to light, and use, and life, if not our citizens? Who recognised that Latin letters were previously debased and prostrate and almost dead, raised them up, restored them, brought them back from death if not our city? ${ }^{47}$

Again, commercial letters are contrasted with nobler ones, this time explicitly, and pleonastically, identified as "Latin letters".

Having established that the final sentence of Bruni's exposition in the Laudation refers to Florence's thriving Latin studies, it follows that his acknowledgement of the city's vernacular culture is even shorter and more grudging than it seems. Bruni exalts the quality of the Florentine language and its speakers, but says not a word about Dante, Petrarch, and Boccaccio. Dante, especially, had long been a source of civic pride in the city, and the subject of public lectures. ${ }^{48}$ It seems likely that Bruni was challenged about this neglect, and produced the Dialogues for Pier Paolo Vergerio in partial response. Yet this text, commonly read as manifesto of the new humanist movement, is no straightforward panegyric like the Laudation and the Funeral Oration or, to an extent, the History. The core of Bruni's contentions - let alone his definitive opinions - can only be approached through a careful unwrapping of the many layers of denial, irony and inversion in this work. This effort will pay off, however, since the analysis of Bruni's views on languages conducted so far serves to solve the supposed contradictions between

${ }^{47}$ Bruni, Nanni Strozzi, ch. 29-30: "Nam quid ego de litteris studiisque nunc dicam? In qua una re maxima quidem ac luculentissima principatus consensu omnium civitati nostre tribuitur. Nec ego nunc de vulgaribus istis mercennariisque, quamquam in illis quoque nostri excellunt, sed de politioribus illis divinioribusque studiis, quorum excellentia maior et gloria sempiterna immortalisque habetur, et loquor et sentio. Quis enim vel nostra vel superiori etate poetam aliquem nominare potest nisi Florentinum? Quis hanc peritiam dicendi iam plane amissam in lucem atque in usum vitamque revocavit preter cives nostros? Quis Latinas litteras prius abiectas atque prostratas et fere demortuas agnovit, erexit, restituit, ab interitu vendicavit nisi civitas nostra?"

48 S. Gilson, Dante and Renaissance Florence (Cambridge, 2005), 54. 
both books, and to explain why this debate on literature is embedded in a discussion of Roman and Florentine history.

Bruni's Dialogues consist of two exchanges set on successive days during Easter 1401. The date is of course significant: the Divine Comedy (ca. 1308-1320) begins on Good Friday 1300 with Dante's descent into Hell, and his journey through Paradise is complete on Easter Sunday; Petrarch's Canzoniere (1336-1374) dates the inception of his misery his love for Laura - to the death of Christ on Good Friday 1327. Bruni thus immediately signals a link between himself and his subjects; however, the symbolism, which in Dante's and Petrarch's writings indicated redemption after sin, now points to rebirth only. Bruni gives the days as "those of the resurrection of Christ"; the year as seven years after the death, in 1394, of Luigi Marsili (1342-1394), a learned monk in the convent of Santo Spirito: in secular terms, it is the first year of the new century. ${ }^{49}$

During both exchanges, the character of Bruni plays only a minor part. The action is set in motion by the aged chancellor Coluccio Salutati, who chides his younger friends for not practicing the art of disputation, by which he means informal, ex tempore debate about any given topic. It is absurd, he says, to talk to oneself between the four walls of one's study, only to then fall silent in public as if one knows nothing. Such disputation, it is worthy underlining, is to be conducted in Latin. This is evident when Salutati chides those "who, although they claim to know [Latin] letters and read books all the time, cannot speak Latin without their books": the contrast is between reading and speaking, not between Latin and another language. ${ }^{50}$ His opponent is Niccolò Niccoli, who in the first dialogue counters that Latin has declined ever since the age of Cicero, and disputation is impossible because the liberal arts were irretrievably lost with the end of antiquity, when ancient texts ceased to be copied. His concern is likewise with Latin culture: he rails against the Aristotelians, marvelling how they learned philosophy when they do not

${ }^{49}$ Bruni, Dialogi, ch. 5: "Ii dies qui pro resurrectione Iesu Christi festi habentur."

${ }^{50}$ Ibid., ch. 9, 8: "Etenim absurdum est intra parietes atque in solitudine secum loqui multaque agitare, in oculis autem hominum atque in coetu veluti nihil sapias obmutescere"; "qui cum litteras scire se profiteantur et libros lectitent, tamen [...] nisi cum libris suis Latine loqui non possunt." 
even know [Latin] letters, and speak in solecisms rather than words. ${ }^{51}$ He also ridicules Dante, Petrarch, and Boccaccio for their lack of learning and Latinity. Yet Niccoli's thesis cannot stand without qualification. He already politely pointed to Salutati as exception to his generalisation, attributing the chancellor's special status to his almost divine intellect. Salutati, mirroring this gesture, in turn praises Niccoli for speaking so excellently in disputation that he disproves his own proposition through his speech. The old man, however, does not return the compliment: he will not believe that Niccoli alone succeeds where others cannot, and therefore the conditions for literary endeavour must be better than his challenger would have it..$^{52}$ Thus prompted, the reader will not fail to notice that the Dialogues themselves, through their existence, disprove Niccoli's thesis in a similar way. Moreover, speaking in his authorial voice in the dedication to Vergerio, Bruni is rather more optimistic than Niccoli about a possible resuscitation of letters: he claims that it is one of the glories of Florence that "of the liberal arts and the whole humanities, which seemed already to have perished completely, some seeds remained here, which indeed grow by the day and soon, I believe, will bring forth no inconsiderable light." ${ } 3$

When the speakers reconvene the next day, Salutati - who disagrees with Niccoli's dismissal of Florence's literary triumvirate - invites Bruni's character to speak in their defence. The latter quickly passes the task back to Niccoli, who thus has to argue against himself. ${ }^{54}$ The young Niccoli and Bruni were close friends at the time; the author even has Salutati remark "that [Leonardo] so agrees with Niccolò's every judgement that I think he would rather be wrong with him than right with me," and Bruni's character indeed puts himself in Niccoli's camp. ${ }^{55}$ Nonetheless, the preface belies a complete identification, so that the

${ }^{51}$ Ibid., ch. 20: "O praeclaros nostri temporis philosophos [...] quos ego nequeo satis mirari quo pacto philosophiam didicerint, cum litteras ignorent. Nam plures soloecismos quam verba faciunt cum loquuntur."

52 Ibid., ch. 33.

53 Ibid., ch. 1: "Etiam optimarum artium totiusque humanitatis, quae iam penitus extincta videbantur, hic semina quaedam remanserunt, quae quidem in diem crescunt, brevi tempore, cum credimus, lumen non parva elatura."

${ }^{54}$ The phrasing lends itself to double entendre (ibid., ch. 1): "Neque est in me tanta dicendi facultas."

${ }^{55}$ Ibid., ch. 31-32: "Ita enim video illum in omni sententia cum Nicolao convenire, ut iam arbitrer potius cum illo errare velle quam mecum recta sequi"; "non sum nescius non magis Nicolai causam quam meam hoc sermone agi." 
question is not so much whether Niccoli functions as Bruni's mouthpiece, but rather which parts of his arguments in this in utramque partem dialogue were in actual fact shared by Bruni. As noted, according to Hans Baron Niccoli's recantation provided proof of the impact of the war with Milan on the development of Florentine humanism: for him, both Niccolis represent the author, but at different times, the first Dialogue pre-dating the death of Gian Galeazzo Visconti, the second plus the preface reflecting Bruni's revaluation of Florentine culture and post-dating the Laudation which is mentioned only in the later part of the text. ${ }^{56}$ Baron's double dating has now been discredited on external and internal grounds, in particular through comparison to Bruni's literary model Cicero's On the Orator (De oratore), in which one of the speakers similarly recants. Furthermore, Niccoli's retraction has rightly been argued to be less convincing than Baron would have it: a change in tone - arch irony replacing aggressive scorn - rather than substance. ${ }^{57}$ But what has gone unnoticed is that Niccoli's recantation differentiates between the authors' Latin and vernacular works. With this distinction in place, the contradictions between both Dialogues melt away. Furthermore, the current state of both languages must be understood in relation to socio-political developments. It is for this reason that in both Dialogues, discussions of Caesar and anti-Caesarism precede Niccoli's evaluations of Dante, Petrarch, and Boccaccio. Specifically, the decline of Latin is juxtaposed with the figure of Caesar, whereas acknowledgement of the bloom of the Florentine vernacular follows a digression on Florence's reassertion of her independence in the face of the proCaesarian Ghibellines.

In the first Dialogue, Salutati - the defender of Trecento culture! proclaims that Dante would not merely have equalled but rather surpassed the ancients if only he had written in Latin: his flaw, it is implied, is that he wrote in the vernacular. ${ }^{58}$ Niccoli vehemently denies

${ }^{56}$ Baron 1966 (as in n. 1), 225-269.

${ }^{57}$ For Cicero's De oratore as model for the Dialogues, see also J. Bertolio, "Non solo stile. Il De oratore come modello dei Dialogi al Vergerio di Bruni", Rinascimento 49 (2009), 245-254; for qualifications of Niccoli's recantation, see especially Quint 1985 and Fubini 1992 (both as in n. 4).

${ }^{58}$ Bruni, Dialogi, ch. 40: "Dantem vero, si alio genere scribendi usus esset, non eo contentus forem ut illum cum antiquis nostris compararem, sed et ipsis et Graecis etiam anteponerem;" "genus scribendi" or "dicendi" can refer to literary style, but here Bruni uses the terms to indicate what is nowadays called language, as is clear from the discus- 
this: Dante's works are flawed in many, and the most basic, respects. He points to elementary failings of literary and historical knowledge in the Divine Comedy: the poet misapplied a passage of Virgil on avarice to prodigality; and portrayed Marcus Cato, still youngish when he killed himself at Utica, as an old man with a white beard. But far worse is Dante's error of judgement concerning Marcus Brutus - noble Brutus, who slew Caesar to win liberty. Niccoli's sketch shows that he considers Caesar a tyrant, who invaded the Republic with arms. He then makes the now familiar claim that, the good citizens having been killed, Caesar stole Rome's liberty. It pains him as a Christian, Niccoli maintains, that Dante put Judas, who betrayed the world's saviour, and Brutus and Cassius, who killed the world's scourge, side by side in Satan's mouths. ${ }^{59}$ But this is a matter of religion, which he will leave be; instead, he will speak of the things pertaining to "our studies". That said, Niccoli immediately launches an attack on Dante's Latin style, which, he claims, was shaped by the tedious quodlibets of the monks. If everything else is granted Dante, it must still be accepted that he lacked Latinity. ${ }^{60}$ Niccoli therefore "remove[s] him from the company of lettered men, and leave[s] him to the girdlers and bakers and their crowd."61 What this means is that, again, Latin and letters are coterminous, and that Niccoli assigns Dante - who was clearly not, in the modern sense, illiterate - to a non-Latinate, that is Florentine-speaking, audience. In his recantation the next day, Niccoli once more lists "woolworkers, cobblers and brokers" as those who love Dante, moreover describing them as "men who never saw letters or tasted the sweetness of poetry." 62 Again the

sion ibid., ch. 83 . This position was indeed expressed by the historical Salutati in a letter dated 1401: see Gilson 2005 (as in n. 48), 61.

${ }^{59}$ Bruni, Dialogi, ch. 43: "mundi vexatorem"; "mundi salvatorem".

${ }^{60}$ Ibid., ch. 44: "De his loquamur quae ad studia nostra pertinent"; "certe Latinitas defuit"; "Latine loqui non possit".

${ }^{61}$ Ibid., ch. 44: "Quamobrem, Colucci, ego istum poetam tuum a concilio litteratorum seiungam, atque eum zonariis, pistoribus atque eiusmodi turbae relinquam."

62 Ibid., ch. 68: "Lanistae, sutores atque proxenetae - homines qui nunquam litteras viderunt, nihilque unquam gustaverunt ex poetica suavitate." In classical Latin, lanista means "gladiator trainer", which cannot apply here; medieval lexica also give "butcher" and "woolworker". The word is translated as the latter in a passage in Bruni's letter to Biondo, cited at n. 98 below, by James Hankins, in Griffiths, Hankins, Thompson 1987 (as in n. 6), 230. Humanist precedents may be found in Petrarch's Contra medicum, in David Marsh (ed., tr.), Francesco Petrarch, Invectives (Cambridge, MA, 2003), 2-179, at 3.108: "Clibanarius et lanista quam necessarii sunt, quam viles!" ("Consider the baker and the woolworker: how necessary they are, and how base!"), and especially in Petrarch's Familiarum rerum libri, 21.15, 22. This letter to Boccaccio is certainly on Bruni's mind, 
reference is to Latin, since it would obviously be nonsensical to claim that readers of Dante have not experienced literature or the sweetness of poetry tout court.

How should one interpret this juxtaposition of Caesar, his killing of Rome's best citizens and freedom, the lack of Latinity that afflicts Dante, and the poet's consequent appeal to those social strata who knew no Latin but only spoke their vernacular? Bruni does not comment. However, at the beginning of Niccoli's speech, he had him state that disputation requires demonstration of the consequences and antecedents, causes and effects. "Everything is related through some kind of wonderful connection," he says, before blaming the loss of disputation on the poverty of the times. ${ }^{63}$ With the evidence from Bruni's other works, it is plain to see that the connection he has Niccoli provide is, in a nutshell, the historical cause of Latin's decline - which still affected the work of Dante. In like vein, Niccoli's revaluations on the second day are preceded by a political-historical sketch that indicates why some cultural growth - in the vernacular if only partially in Latin - has since been possible, as will be shown now.

On the second day, the conversation takes its course from a comment of Salutati's concerning the beauty of Florence, which leads one of the speakers, Pietro Sermini, to recapitulate the main topics of Bruni's Laudation. For particular praise he singles out the passage, already mentioned, in which Bruni showed that the cause of "our side", the Guelfs, had a splendid origin and was taken up rightfully; whilst "you visit the greatest infamy upon the Caesarian faction, which is hostile to ours, by relating their crimes and by lamenting the liberty of the Roman people." 64 This view is qualified by Salutati - exponent of the older

as in it, Petrarch defends himself against the claim that he scorned Dante, whilst disparaging the esteem in which the latter was held by lowly artisans: "Nisi forte sibi fullonum et cauponum et lanistarum ceterorumve, qui quos volunt laudare vituperant, plausum et raucum murmur invideam" ("Unless perhaps I envied him the applause and raucous acclaim of the fullers or tavern keepers or woolworkers who offend the ones whom they wish to praise"). See U. Bosco (ed.), Francesco Petrarca, Le familiari, vol. 4 (Firenze, 1968), 99; and A. Bernardo (tr.), Francesco Petrarch, Letters on Familiar Matters XVII-XXIV (New York, 2005), 206.

${ }^{63}$ Ibid., ch. 16: "Itaque tenenda probe res est de qua disputare velis; nec ea solum, sed consequentium, antecedentium, causarum, effectuum, omnium denique quae ad eam rem pertinent habenda cognitio"; "Omnia sunt inter se mira quadam coniunctione annexa."

${ }^{64}$ Ibid., ch. 57: "Verum illud maxime in ea oratione me delectavit: quod studia partium nostrarum et a praeclaro initio et merito atque optimo iure ab ea civitate probas suscepta. Caesaream vero factionem, quae huic nostrae inimica est, referendo eorum scelera et de- 
generation - who was historically the author of On the Tyrant (De tyranno, 1400), which argued for the legitimacy of Caesar's rule. In the Dialogues, he stands by that conclusion, and suggests that Bruni's attack in the Laudation was made merely for the sake of the argument: "It was, to be sure, necessary for Leonardo [...] once he had taken it upon himself to glorify the cause of this city, to inveigh somewhat against the Caesars." ${ }^{65}$ Nonetheless, he professes himself in full accord with the panegyric's analysis of the origins of the Guelf faction: the defeat of king Manfred in 1266, Salutati states, was not the birth, but the splendid restoration of Florentine Guelfism, so that Bruni's historical framework remains uncontested. ${ }^{66}$ Mention of this glorious Florentine victory then causes another participant, Roberto de' Rossi, to demand that yesterday's conversation be continued with a celebration of Dante, Petrarch, and Boccaccio, "who are not the least of Florence's glories." 67 In this way, the rebirth of the city's Guelf independence ushers in the - this time positive - evaluation of the Florentine tre corone.

Yet in his recantation, Niccoli does not fully reverse his earlier positions. Two aspects remain unredeemed. One is the status of Caesar. When Niccoli is invited to sing Dante's praises, he does not alter his assessment of the dictator in any way, nor does he bother to take issue with the arguments of On the Tyrant to which Salutati had referred. Instead he proposes that, since Caesar's invasion of Rome and suppression of liberty were so clearly criminal, Dante must have meant the passage to be read allegorically: "In Caesar he feigned a legitimate prince and a just monarch in worldly affairs; in Brutus a seditious, rebellious and criminal man, who sinfully slew this prince." 68 The parallel punishments meted out to Judas and the tyrannicides thus neatly juxtapose an allegory of just worldly rule with the heavenly rule of Christ,

plorando libertatem populi Romani in summam invidiam adducis." Piero Sermini was a young friend of Salutati's, who succeeded him as chancellor.

${ }^{65}$ Ibid., ch. 58: "De qua quidem re satis a me diligenter, ut mihi videor, in eo libro quem de tyranno scripsi disputatum est, bonisque rationibus conclusum non impie Caesarem regnasse. [...] Necesse id quidem Leonardo fuit [...] ad causam huius civitatis, quam susceperat, exornandam, ut in Caesares ipsos aliquanto inveheretur."

${ }^{66}$ In the History, 2.2, Bruni moved this rebirth back in time, to the death of emperor Frederick II.

${ }^{67}$ Bruni, Dialogi, ch. 61: "Nam tres illi vates non minima pars gloriae sunt huius nostrae civitatis."

${ }^{68}$ Ibid., ch. 76: "Sed legitimum principem et mundanarum rerum iustissimum monarcham in Caesare finxit; in Bruto autem seditiosum, turbulentum ac nefarium hominem, qui hunc principem per scelus trucidaret." 
and Niccoli therefore claims to have no doubt that this is the reading that Dante intended. Those who condemn Brutus' deed as impious, he says, must either be flattering the emperors or the Ghibellines. ${ }^{69}$ If this volteface saves Dante's reputation, it does nothing to vindicate Caesar or Salutati.

Second, while Niccoli lets Dante off the hook regarding Caesar, and also excuses his supposed factual errors - Dante used poetic liberty with the Virgil passage, and represented the soul not the body of Cato - he does not revise his judgement on his Latin. The exposition in which Niccoli praises Dante's eloquence concerns the Comedy: it is thus in Florentine, not Latin, that Dante spoke well. ${ }^{70}$ About his Latin, Niccoli merely acknowledges that Dante wrote it, and therefore cannot have been ignorant of it: his contrary claim the previous day, he says, was merely to provoke a response from Salutati. Even here, however, the phrasing allows for double entendre: "For who in his right mind," Niccoli asks, "could quietly accept that a man who so frequently debated, who wrote heroic poems, who was commended by so many studies that he did not know Latin?"71

Niccoli pursues different yet comparable strategies with Petrarch. To begin, he does not speak in his own voice, but instead reports the words of Petrarch's friends whom he once visited in Padua. Their account is in fact a variation on a 1379 letter of Salutati's: the argument is that Petrarch surpassed the writers who came before him since he, unlike his predecessors, mastered both poetry and prose. ${ }^{72}$ This invites a list of Petrarch's Latin works in both genres, to which Niccoli adds that he also wrote very elegantly in the popular genre of speech, "as well as in the other genres." 73 Then, speaking as himself, Niccoli proffers a pseudoinversion of his claim, made in the first Dialogue, to value a single verse of Virgil or one letter of Cicero over Petrarch's entire output: he now states that he prefers one oration of Petrarch to all Virgil's letters, and

${ }^{69}$ Ibid., ch. 77: "Non desunt enim auctores qui, vel propter affectionem illarum partium, vel ut imperatoribus placerent, factum illud Bruti scelestum atque impium vocent."

${ }^{70}$ Ibid., ch. 71.

${ }^{71}$ Ibid., ch. 78: "Nam qui sanae mentis aequo animo haec audiret, qui totiens disputarit, qui carmina heroica scripserit, qui per tot studia approbatus fuerit, eum litteras ignorasse?"

${ }^{72}$ Adressed to Giovanni Bartolomei, discussed in Quint 1985 (as in n. 4), 440.

${ }^{73}$ Bruni, Dialogi, ch. 83: "Adeo autem illum ad omne genus scribendi ingenium accommodasse, ut ne populari dicendi genere se abstinuerit, sed in hoc, ut in ceteris quoque, elegantissimum et facundissimum videri." These works are the Africa, Bucolicum carmen, Epystolae metricae, and many prose books and letters. 
Petrarch's poems to all those of Cicero. ${ }^{74}$ Of course, no letters of Virgil are extant, and only disappointing snippets of Cicero's poetry survive: Niccoli's remark can only be called "a malicious joke". ${ }^{75}$ Petrarch's selfproclaimed masterpiece, the Latin Africa, provokes the comment that it surely would have been better if the author had not died before polishing the text. However, echoing Bruni's preface, Niccoli does give Petrarch full credit for opening the way to a restoration of the study of letters, which in his day were dead and gone. ${ }^{76}$

Last and indeed least, Niccoli cursorily praises Boccaccio's learning, eloquence and charm, which applies to his Latin (listed first) as well as his Italian writings. ${ }^{77}$ Yet since his statement in the first book, that Boccaccio is inferior to Dante and Petrarch, remains unrevised, this does nothing to alter his overall assessment. ${ }^{78}$ In conclusion, Niccoli congratulates the three poets on their achievements in the face of the intellectual poverty of their times. As such, Niccoli's so-called recantation - for all the ornate words he expends upon the three crowns - remains indifferent to Boccaccio; lauds Dante's qualities as a vernacular poet for the nonLatinate crowd but does not recommend his Latin; and disparages Petrarch's Latin writings while briefly nodding to his vernacular poetry yet praises him unreservedly for his role as harbinger of a Latin revival.

As such, the two books of the Dialogues are hardly contradictory, once it is realised that the positive evaluation in the second pertains particularly to Dante's vernacular magnum opus but not to the Latin of the three crowns, which the author continues to depict as imperfect. They are connected, furthermore, by the framework of historical causation in which Bruni embeds his evaluations, which sets up Caesar as the inverse mirror of the anti-imperial Guelfs. The only persistent difference between Bruni and both Niccolis lies in the author's belief that a revival of

74 Ibid., ch. 86 (cf. ch. 50): "Ut dicam me orationem Petrarchae omnibus Vergilii epistolis, et carmina eiusdem vatis omnibus Ciceronis carminibus longissime anteferre."

75 E. Gombrich, "From the Revival of Letters to the Reform of the Arts. Niccolò Niccoli and Filippo Brunelleschi”, in D. Fraser, H. Hibbard, M. Lewine (ed.), Essays in the History of Art Presented to Rudolf Wittkower (New York, NY, 1969), 71-82, at 73.

${ }^{76}$ Bruni, Dialogi, ch. 85: "Hic vir studia humanitatis, quae iam extincta erant, repararit et nobis, quemadmodum discere possemus, viam aperuerit."

77 These works are the Genealogia deorum gentilium; De montibus, silvis, fontibus, lacubus, fluminibus, stagnis seu paludibus et de nominibus maris liber; De casibus virorum illustrium; De mulieribus claris; and the Bucolica carmina, followed by works about "loves and nymphs" which may refer to a range of Boccaccio's vernacular poems, perhaps especially the Amorosa visione, Filostrato, and Ninfale fiesolano.

${ }^{78}$ Bruni, Dialogi, ch. 87. 
Latin is within reach. Since his Dialogues both state and demonstrate this conviction, they present his own generation of humanists as the first fully to achieve this renaissance.

\section{Speech and the City}

What would be the purpose of this restored classical Latin? In the Dialogues, Salutati asserted - a claim unopposed by Niccoli - that Latin should not be restricted to one's study, but spoken in public, and without books: in other words, it ought not to be reserved for the contemplative life but embrace the active life also. ${ }^{79}$ This raises the question of the respective domains of Latin and Florence's other language, her vernacular. To shed light on this matter, it will be useful to return to the Laudation, where Bruni first juxtaposed the two, and compare his panegyric to its model, the Panathenaicus of Aelius Aristides. ${ }^{80}$

The Panathenaicus, a eulogy on Athens, was delivered at the city's most important festival, the Panathenaia, in $155 \mathrm{AD}$, and is in part a speech about speech. After discussing Athens' geography, her origins, and her historic military victories - the same sequence of topics pursued by Bruni in the Laudation - Aristides dedicates the last part of the oration to the Attic language and Athenian cultural hegemony. Indeed, he explicitly introduces the topic of speech as necessary to the genre of epideictic oration: "For it seems to me as if it were improper to praise actions with speech and then to omit mentioning the topic of speech itself." "81

With this statement, Aristides creates an intertextual relationship between his own work and Pericles' funeral oration in Thucydides' History of the Peloponnesian War. This address is the first eulogy of Athens on record; Bruni himself later used it as a model for the praise of Florence contained in his Funeral Oration for Nanni Strozzi. In this speech, Thucydides has Pericles contrast the great deeds of the Athenians with the inferior words in which he reports them..$^{82}$ Aristides, chiding those who speak but do not discuss speech, thus creates an identity of

${ }^{79}$ Ibid., ch. 9, discussed above.

80 The parallels between both eulogies were already noted by Baron 1966 (as in n. 1), 192-195, but the extent and meaning of Bruni's debt have remained surprisingly unexamined.

81 Aelius Aristides, Panathenaicus, in C. Behr (tr.), The Complete Works, vol. 1: Orations I-XVI (Leiden, 1986), 5-77 [henceforth Aristides, Panathenaicus], ch. 322.

82 Thuc. $2.35-46$, at 2.35 . 
form and subject that resolves the tension pointed to by Pericles. ${ }^{83}$ This intertextuality between Aristides and Thucydides indicates an important motive in the Panathenaicus. Pericles spoke in 431 BC, when Athens was at the height of her political powers and at the head of her own insular empire. Aristides, on the other hand, delivered his speech at a time when the city had long been incorporated into the Roman Empire. She no longer enjoyed political and military independence, and her status as nominally free city was owed to Rome's respect for her cultural heritage, as Aristides acknowledges. ${ }^{84}$ This forms the background to the orator's assertion - which follows his account of the Athenian triumphs over Persia half a millennium before - that Athens' greatness is not in fact defined by politics or war, but by language instead. Aristides claims that "all other dialects - to say nothing about the barbarians, but I mean of the Greeks themselves - were like the words of lisping children in comparison with yours," and hence "all the cities and all the races of mankind turned to you and your form of life, and dialect." ${ }^{\circ 5}$ If these lines sound familiar, it is because these were translated almost literally, and applied to the Florentine dialect, by Bruni in his Laudation.

Aristides furthermore claims that the Attic dialect, and only the Attic dialect, is appropriate for civic functions: "[This Attic] dialect alone is suitable for all national festivals, all assemblies and council chambers." ${ }^{\prime 86}$ He explains these qualities of Attic as a function of Athens' central location, which, as he noted in the first part of the speech, ensured a language that was "clear, pure and pleasant" and free from barbarian influences ${ }^{87}$ There, Athens' centrality was visualised through a series of concentric circles:

The city occupies the same position in its territory as its territory does in Greece, for it lies in the very centre of a central land [...]. And as a third centrality after these, there rises clear aloft through the midst of the city, what was the old city and what is now the present Acropolis, like a mountain peak [...]. As if on a shield layers have been set on one another, in fifth place, the fairest among all fills the area up to the

${ }^{83}$ E. Oudot, "Aelius Aristides and Thucydides. Some Remarks About the Panathenaic Oration", in W. Harris, B. Holmes (ed.), Aelius Aristides between Greece, Rome, and the Gods (Leiden - Boston, MA, 2008), 31-50, at 44-45.

${ }^{84}$ Aristides, Panathenaicus, ch. 332.

${ }^{85}$ Ibid., ch. 322-327.

${ }^{86}$ Ibid., ch. 327.

87 Ibid., ch. 15. 
boss: [so] Greece is in the centre of the whole earth, and Attica in the centre of Greece, and the city in the centre of its territory, and again its namesake in the centre of the city. ${ }^{88}$

In other words, the Acropolis, which was the main site of Athens' civic religion as well as of a number of government functions, stood as the very centre of this central city. As such, Athens' civic, linguistic, and geographical centres coincided in Aristides' exposition. Furthermore, since Athens' foremost festival, the Panathenaia, took place on the Acropolis, and this is where Aristides held his eponymous oration, he placed himself in the linguistic heart of Athens, where he delivered his oration both claiming and showing the excellence of Attic speech.

This passage obviously lies at the basis of Bruni's visual representation of the topography of Florence and her contado, likewise in the first part of his panegyric:

For just as on an embossed shield, with circles closing on each other in turn, the innermost of the circle finishes in the navel which is the middle point of the whole shield, in the same way and manner we see here regions, as if they were circles, closing in on and surrounding each other. The first of these is the city, as a navel in the middle of her whole surroundings. But she is enclosed by walls and suburbs. Country houses then surround the suburbs, and towns surround the country houses; and this whole outermost region is enveloped by a larger orbit and circle. ${ }^{89}$

Moreover, Bruni also elevates a civic centre, the Florentine version of the Athenian Acropolis. For this role, he chooses the Palazzo della Signoria (now Palazzo Vecchio), seat of the Florentine government. This is a significant choice - he could have proposed the Duomo or Baptistery as city centres instead - that defines Florence as a political community:

${ }^{88}$ Ibid., ch. 16 (punctuation adapted).

${ }^{89}$ Bruni, Laudatio, ch. 21: "Quemadmodum enim in clipeo, circulis sese ad invicem includentibus, intimus orbis in umbelicum desinit, qui medius est totius clipei locus: eodem hic itidem modo videmus regiones quasi circulos quosdam ad invicem clausas ac circumfusas. Quarum urbs quidem prima est, quasi umbelicus quidem totius ambitus media. Hec autem menibus cingitur atque suburbiis. Suburbia rursus ville circumdant, villas autem oppida; atque hec omnis extima regio maiore ambitu circuloque complectitur." For diagrams of the respective circular structures of Aristides and Bruni, see A. Santosuosso, "Leonardo Bruni Revisited. A Reassessment of Hans Baron's Thesis on the Influence of the Classics in the Laudatio Florentinae urbis", in J. Rowe (ed.), Aspects of Late Medieval Government and Society. Essays Presented to J.R. Lander (Toronto London, 1986), 25-51, at 32. 
But in the midst of the buildings rises a most imposing fortress of great beauty and wonderful appointment, which by its appearance readily reveals for what purpose it was built. For just like in a great fleet the flagship will be such that it is immediately clear that she carries the admiral who guides and leads the others, so the aspect of this fortress is such that anyone can understand that there dwell the men who are the governors of the state. For it is so magnificently constructed, and stands so tall, that it vastly dominates the surrounding buildings, and her tower appears more than a private one. ${ }^{90}$

Bruni's debts to Aristides in these passages are evident and abundant. However, he parts ways with the Panathenaicus regarding the link between language and location. Unlike, mutatis mutandis, Aristides, Bruni does not connect the central position of the city and the Palazzo to the qualities of the Florentine languages. These are not mentioned as physical attributes of Florence in the opening section of the Laudation on the city's topography, but only introduced as final paragraph of the fourth and last section, in which Bruni discusses the mechanisms of the Florentine government. This deviation from the Panathenaicus makes sense in the light of Bruni's larger message compared to that of Aristides. The Greek orator privileged Attic as civic language to compensate for Athens' loss of political and military power. Conversely, Bruni saw language as a function of the freedom and self-government of the state, as his later works set forth. That the final section of his panegyric, which discusses the institutions claimed to constitute Florence's freedom, concludes with a tribute to her languages, is therefore not an after-thought, but the culmination of a causal connection. Florence's linguistic bloom follows from the city's political organisation.

Furthermore, Bruni could hardly claim a link between the quality of Florence's languages and her natural geographical position, since one of them - Latin - was neither indigenous nor natural. And yet, as has become clear, Bruni retained Aristides' notion - or saw his own beliefs confirmed - that not all languages are equal, and only some are suited to

90 Bruni, Laudatio, ch. 13: "Per media vero edificia superbissima insurgit arx ingenti pulchritudine miroque apparatu, que ipso aspectu facile declarat cuius rei gratia sit constituta. Ut enim in magna classe pretoria navis eiusmodi esse solet ut facile appareat in illa vectari ducem qui ceterorum sit moderator et princeps, sic huius arcis ea species est ut quivis iudicare possit in ea habitare viros qui gubernatores sint rerum publicarum. Sic enim magnifice instructa est, sic precelsa insurgit, ut omnibus que circa sunt edibus latissime dominetur, appareatque eius plus quam privatum fastigium." 
the highest purposes: like Attic for Aristides, so Latin for Bruni. Describing Florentine as the "popular and common mode of speaking", while Latin was "worthy of free men" and "flourished among all sovereign people", it would seem that Bruni attributed to Latin rather than to Florence's indigenous language the prerogative of Aristides' Attic, namely to be used in "national festivals, all assemblies and council chambers." 91 In other words, Latin rather than the Florentine vernacular appears the suitable language for civic functions. To test this hypothesis, a consideration of contemporary Florentine practice will be instructive.

Like the Athenian acropolis, the Palazzo della Signoria, elevated by Bruni as civic centre, functioned as a site of civic speech. Political ceremonies, including the bimonthly investiture of the Florentine governing body of the Priors, took place at the Palazzo and were marked by speeches from the ringhiera, the raised speakers' platform which was attached to it and projected onto the square. ${ }^{92}$ Policy was also publicly debated on the ringhiera, and a number of fourteenth-century Florentine treatises on the ars concionandi, which teach the composition of such deliberative orations, testify to the importance of this type of public speech. ${ }^{93}$ The identification of the political centre with speech was sufficiently strong for a false etymology to explain the word palazzo as parlagio, a place of speaking on a par with parliamento. ${ }^{94}$ In terms of sound rather than speech, moreover, the Palazzo's bell-tower, named the Leone, so prominent in Bruni's panegyric, rung out when the new Priors entered the Palazzo, as well as daily chiming the Ave Maria to call the citizens for evening prayer. ${ }^{95}$

A significant part of this civic speech was in Latin. The Florentine government in Bruni's day was, in fact, bilingual. ${ }^{96}$ Externally, Latin

${ }^{91}$ Ibid., ch. 91; Aristides, Panathenaicus, ch. 327.

92 The name of the ringhiera in fact derives from the verb aringare, meaning to deliver a speech: S. Milner, "Citing the ringhiera. The Politics of Place and Public Address in Trecento Florence", Italian Studies 55 (2000), 53-82, at 60.

${ }^{93}$ S. Milner, "Communication, Consensus and Conflict. Rhetorical Precepts, the ars concionandi and Social Ordering in Late Medieval Italy", in V. Cox, J. Ward (ed.), The Rhetoric of Cicero in its Medieval and Early Renaissance Commentary Tradition (Leiden, 2006), 365-408.

${ }^{94}$ Milner 2000 (as in n. 92), 72.

${ }^{95}$ N. Atkinson, "The Republic of Sound. Listening to Florence at the Threshold of the Renaissance", I Tatti Studies in the Italian Renaissance 16.1/2 (2013), 57-84, at 74.

${ }^{96}$ See F. Klein, "Leonardo Bruni e la politica delle Consulte e Pratiche", in Viti 1990 (as in n. 7), 157-174, at 164-165; Rizzi 2013 (as in n. 34), at 244, 248; also Witt 2000 (as in n. 38), 361. 
was the medium for diplomacy, within Italy as well as further afield: virtually all correspondence of the republic was composed in that language, at the time of the Laudation by the chancellor Salutati. Within the palazzo, there were two languages of government: council meetings were conducted in the vernacular (unless foreigners were present, when Latin was used), but recorded in Latin or in a mixture of both languages. Formal speeches delivered from the ringhiera also tended to be in Latin - indeed, if Bruni ever delivered the Laudation, the ringhiera would have been the likely venue, in which case the panegyric's final passage repeats Aristides' manoeuvre of proclaiming as well as showing the qualities of the city's speech from her central civic site. On the other hand, the deliberative oration taught in the ars concionandi was in Florentine. Thus the domains of both languages were not informed by oral versus written discourse, nor by domestic versus foreign affairs. Rather the choice of language appears to reflect the permanence of the utterance: discourse that needed to be consultable, such as records and diplomatic exchanges, or purported to be unchanging or definitive, such as ritual and ceremonial speech, was cast in Latin, whereas the deliberations that preceded policy decisions were expressed in the vernacular.

Regarding these enduring political transactions, there can be no doubt that Bruni - who took such pride in the classicism pioneered in Florence - believed that humanist Latin should replace the medieval Latin of the chancery. This process was, indeed, already underway in Salutati's public letters. More questionable is whether Bruni thought that humanist Latin should also replace the vernacular as language of non-permanent, non-ceremonial political speech - including, for instance, the deliberations of the ars concionandi at the time conducted in Florentine. Such a scenario would, of course, enhance enormously the value of humanists as civil servants, and as educators of the governing classes. It would, equally, entail an unprecedented exclusion of the non-Latinate classes from the theatre of politics. And yet, this arrangement is far from unthinkable since, according to Bruni, there was a precedent. Rome, in her republican heyday, had been governed the precise same way.

This is evident from Bruni's letter concerning the Roman language addressed to Biondo Flavio. Arguing that Latin was spoken by all Romans, Biondo had adduced as evidence that the common people of Rome understood the language plays of Plautus and Terence, and the oratory of Cicero. Bruni rebuts these points as follows. Comprehension 
of the plays, he claims, was aided by the spectacle, the acting, and the synopses of the plot offered before the performance, without which the actors themselves would barely have known what they were saying. ${ }^{97}$ Regarding popular understanding of political oratory, he writes:

First, that the orators spoke Latin and literately in the senate and in law courts contributes nothing to your position. For the speech of the orator in the senate and courts was aimed at lettered men. So those two places have nothing to do with your case. Remains the contio, in which an oration was addressed at learned and unlearned men simultaneously. For that term [sc. contio] not only signifies a crowd of people and men of the lowest sort, but the noble as well as those of humble birth, the learned and unlearned. So the orator spoke not so much to the bakers and woolworkers, but much more to those who were involved with the government of the republic, and to whom it mattered what the people decreed. So the worthier men understood the orator clearly when he spoke at the contio in Latin and literately, but the bakers and woolworkers and that sort of crowd understood the words of the orator as they now understand the observance of the Mass. ${ }^{98}$

This passage - stunning in its elitism - immediately puts to rest any assumption that Bruni envisaged ancient Rome as a participatory democracy: the language barrier effectively precluded the uneducated from partaking. Latin was an instrument of politics, but also of political exclusion: a tool firmly in the hands of the oligarchic government of the Roman Republic. Two other things stand out, inviting direct parallels with Florence. The first is the identity of the Roman people who did not speak Latin, whom Bruni names as the bakers and the woolworkers. In the Dialogues, it was the same Florentine "girdlers and bakers and their crowd," and "woolworkers, cobblers and brokers" to whom Niccoli left

${ }^{97}$ Bruni, “An vulgus”, 216-218.

98 Ibid., 216-217: "Primum igitur oratores quod in senatu iudiciisque Latine litterateque loquerentur, nichil opinionem tuam adiuvat. Erat enim in senatu et iudiciis ad homines litteratos oratoris sermo. Itaque haec duo loca nichil ad rem pertinent tuam. Restat concio, in qua ad doctos simulque indoctos habebatur oratio. Neque enim appellatione populi turba solum et infimae sortis homines, sed nobiles et ignobiles, doctique et indocti significabantur. Itaque non ad pistores tantum et lanistas, sed multo magis ad eos qui in reipublicae gubernatione versabantur, et quorum intererat quid populus decerneret, orator loquebatur. Praestantes igitur homines oratorem Latine litterateque concionantem praeclare intelligebant, pistores vero et lanistae et huiusmodi turba sic intelligebant oratoris verba ut nunc intelligunt Missarum solemnia." The translation of lanista is discussed in $n .62$ above. 
Dante's Divine Comedy, since they "never saw Latin or tasted the sweetness of poetry." 99 Secondly, the occasions on which these Roman artisans heard, but did not fully comprehend, Latin - the contiones - are the functional and etymological ancestors of the Florentine deliberative orations taught in the ars concionandi. In other words, the Romans had used their elevated language also for ephemeral political discourse, instead of relying on their own vernacular. They had done so, moreover, notwithstanding the lack of popular comprehension of Latin. There is therefore no obvious reason why this same arrangement could not be replicated in Florence. Is this, then, what Bruni had in mind?

If so, Bruni's thinking was nothing short of revolutionary. For a restitution of Latin's political function, and a recreation of Roman bilingualism, would constitute a fundamental overhaul of the principles of Florentine governance. Like their Roman counterparts, the woolworkers, bakers, and their ilk, would be left without political voice. To grasp the significance of this proposition, one should be aware that the bakers were one of the seven minor guilds represented in the Florentine government. That is to say, they had limited, but nonetheless some, political rights. The woolworkers, on the other hand, may be identified as the ciompi (Florentine for woolworker), who were not allowed to form their own guild and therefore had virtually no political representation. In order to obtain it, they had led the "Revolt of the Ciompi" in 1378. This had resulted in an alliance of artisans headed by the woolworkers standing at the helm of the most popular government in Florence's history until $1384 .{ }^{100}$ Then a counterrevolution dethroned the Ciompi, instituting a much narrower regime, and the period of Ciompi rule was spoken of by the governing elites with fear and horror ever after. ${ }^{101}$ Subsequently, electoral reforms progressively brought power in

${ }^{99}$ Bruni, Dialogi, ch. 44, ch. 68.

${ }^{100}$ The ciompi were represented by the arte della lana, which was one of the major guilds and operated in the interests of the wool merchants rather than workers. On the Ciompi Revolt, see A. Stella, La Révolte des Ciompi. Les hommes, les lieux, le travail (Paris, 1993); on the electoral reforms, see Najemy 1982 (as in n. 3), 263-300.

${ }^{101}$ E.g. F. Novati (ed.), Coluccio Salutati, Epistolario, vol. 2 (Roma, 1893), 84-86 (21 August 1383, letter addressed to Antonio Chelli): "In sordidorum hominum manibus, quorum qualis sit mens et quanta discretio horrendo quadraginta dierum imperio, quibus pestis illa deseviit, notum est"; "Hominum, inquam? Imo non hominum, sed truculentissimarum beluarum"; "Gens illa vilis et sordida [...] Gens illa pauper et inops, infida, mobilis et rerum novarum avida;" also the anonymous continuator of the Acciaiuoli chronicle cited in Milner 2000 (as in n. 92), 58, n. 19. 
the hands of the upper classes, a process that was ongoing at the time of the Laudation. The institution of Latin as the medium of the city's governance would ward off any threat of a reprisal of this episode, since the lower classes, who at present could partake in deliberations in the piazza, would no longer be able to speak the language of politics. ${ }^{102}$

Bruni never comments on whether this was his desired outcome although Salutati's contention in the Dialogues that Latin should be spoken in public, among crowds or perhaps assemblies, points that way. ${ }^{103}$ What can be said with certainty is that the idea does not jar with Bruni's interpretation of republicanism. It has been argued that, rather than being generically republican, civic humanism should be seen as the specific ideology of the post-Ciompi oligarchic regime. Paying lip service to the ideals of equality before the law and broad-based political representation, in fact this lofty rhetoric served to reconcile the majority of the population to their increasing marginalisation, so the argument runs. ${ }^{104}$ It is certainly the case that Bruni's republicanism in the Laudation displays strong aristocratic tendencies. To be sure, Bruni attributes a number of egalitarian principles to the Florentine administration, especially when it comes to access to justice; but legal protection does not equal political participation. ${ }^{105}$ Furthermore, while he makes it clear that a state should not be ruled by the arbitrary command of one man, nor subject to the self-interest of a small oligarchy, Bruni also seems to regard the people's power as a threat. His assertion that "among other peoples the majority can defeat the best men, yet in this city the better and the greater number always appear to be one," shows what he believed to be the proper relationship between the common people and their superiors. ${ }^{106}$ Moreover, he attributes the greatest importance of all magistracies to the leaders of the Guelfs, whose vigilance is expected to ensure that the state does not stray off the ancestral path, or is handed

102 For the tumultuous nature of such popular discussions in the town square, see Milner 2000 (as in n. 92), 70-71, who concludes the section by noting that "for the elite wishing to maintain pre-eminence, it was clear that control of the spoken word was of fundamental importance in sustaining political order." By the end of the fifteenth century, such popular meetings were banned.

${ }^{103}$ Bruni, Dialogi, ch. 9.

104 Najemy 1982, 301-317, and Id. 2000; Gilli 2004 (all as in n. 3).

${ }^{105}$ Bruni, Laudatio, ch. 88-89.

${ }^{106}$ Ibid., ch. 51: "Sed in aliis quidem populis maior pars sepe meliorem vincit; in hac autem civitate eadem semper videtur fuisse melior que maior." 
over to men "of a different persuasion". These eminent citizens he calls the Florentine equivalents of the Roman censors, Athenian Areopagites and Spartan ephors. ${ }^{107}$ Particularly the censors and the Areopagites were seen as aristocratic elements in their respective constitutions; indeed in the Panathenaicus, Aristides cites the Areopagus as an archetypical aristocracy. ${ }^{108}$ Bruni's portrait of Florence is thus not of a popular republic - the guilds are never mentioned as foundations of political representation - but of an aristocratic or mixed regime. ${ }^{109}$ Mixed is indeed how

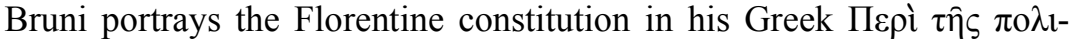
$\tau \varepsilon i ́ \alpha \varsigma \hat{\omega} v \Phi \lambda \omega \rho \varepsilon v \tau i ́ v \omega v$ (1439), written for the discerning eyes of the Byzantine delegates to the Council of the Church which was then in progress in the city. ${ }^{110}$

Rome, of course, was also commonly described as a mixed regime, although in practice her governance was highly oligarchic. ${ }^{11}$ Bruni's careful study of Cicero had alerted him to the workings of the Roman state and how it differed from Florence: this may well be why, while deriving the virtues and political affiliation of the Florentines from her Roman foundation, the Laudation never claims that the city's governing institutions were inherited from Rome. ${ }^{112}$ The Roman Republic did not

107 Ibid., ch. 87: "Positus est enim quasi in vigilia quadam atque custodia, ne res publica e curriculo a maioribus observato deflectat, neve ad homines diversa sentientes administratio rei publice deferatur. Quod igitur Rome censores, Athenis areopagite, Lacedemonie ephori, hoc sunt in Florentina civitate partium duces, id est, ex his civibus qui bene de re publica sentiunt primarii viri electi ad rem publicam tuenda." See also ch. 84 for their supreme importance.

108 Aristides, Panathenaicus, ch. 385.

109 More strikingly still, the only time that Bruni attributes a role to the guilds in the History of the Florentine People is, negatively, in his account of the Ciompi Revolt: Bruni, History, 9.4.

${ }^{110}$ Bruni's On the Constitution of the Florentines is edited and contextualised by A. Moulakis, "Leonardo Bruni's Constitution of the Florentines", Rinascimento 26 (1986), 141-190; an English translation is available in E. Cochrane, J. Kirschner (ed.), The University of Chicago's Readings in Western Civilisation, vol. 5: The Renaissance (Chicago, IL, 1986), 139-144.

111 The locus classicus is Polybius, 6.11-18, which is not, however, believed to have been known in Florence at the time, see A. Momigliano, "Polybius' Reappearance in Western Europe", in Id. (ed.), Essays in Ancient and Modern Historiography (Middletown, CT, 1977), 79-98; J. De Keyser, "Polybius", in G. Dinkova-Bruun (ed.), Catalogus Translationum et Commentariorum. Mediaeval and Renaissance Latin Translations and Commentaries, vol. 11 (Toronto, 2016), 1-60; and J. Hankins, "Europe's First Democrat? Cyriac of Ancona and Book 6 of Polybius", in A. Blair, A.-S. Goeing (ed.), For the Sake of Learning. Essays in Honor of Anthony Grafton (Leiden, 2016), 692-710.

112 Bruni, Laudatio, esp. ch. 43 for the legacy of Rome's virtue. 
offer the average citizen participation in government except through annual voting, which was moreover heavily weighed against the lower classes. The governing elites were drawn overwhelmingly from the city's upper echelons, determined by both birth and wealth. But since Roman political careers were made by the word or the sword, such inherited advantages should be complemented with rhetorical competence and, ideally, military experience. As such, political life was also open to exceptionally talented provincials, who could rise to the top based on their military or oratorical skills. Bruni's linguistic model Cicero, who hailed from Arpinum and rose to consul of Rome, was an example of the latter category.

Likewise, humanism's cultural ideals, while excluding the lower classes, promised inclusion to those who could afford and had aptitude for learning. Through their Latin literacy, humanist professionals attached themselves to the established socio-political elites; by classicising political speech, furthermore, they created and monopolised a tool that regulated access to power. This is what drove the success of the humanist schools of Guarino Veronese (1374-1460) and Vittorino da Feltre (1378-1446) in the next decades, when a humanist education became indispensable for a career as civil servant or courtier. ${ }^{113}$ It was also the career path pursued by Bruni himself, who came from Arezzo which stood in relation to Florence not unlike Arpinum to Rome - and relied on his talent for letters to gain employment in the city and, ultimately, Florentine citizenship. Indeed, the fact that Bruni not merely translated but rewrote Plutarch's biography of Cicero as the Cicero novus (1415) suggests an interest in the Roman orator that went beyond his linguistic skills. ${ }^{114}$ Humanism, therefore, whatever its proclaimed

\footnotetext{
${ }^{113}$ For a humanist education as an asset for patrician Florentine youths, see Witt 2000 (as in n. 38), esp. 444-449 and 499; its value for other future diplomats and courtiers is also stressed by A. Grafton and L. Jardine, "Humanism and the School of Guarino. A Problem of Evaluation", Past \& Present 96 (1982), 51-80. Worth noting is also Gene Brucker's evidence for increasing reference to classical sources in the Florentine Consulte e Pratiche from ca. 1413 onwards, which he links to a new style of consultation and debate, in which speakers no longer acted as representatives reporting the position of corporate bodies such as guilds, but rather as independent individuals who strove to persuade through eloquence, "Humanism, Politics and the Social Order in Early Renaissance Florence", in S. Bertelli, N. Rubinstein, C. Smyth (ed.), Florence and Venice. Comparisons and Relations, vol. 1 (Firenze, 1979), 3-11.

114 The Cicero novus (1415), addressed to Niccoli, is available in Bernard-Pradelle 2008 (as in n. 15), 408-547; for Bruni's innovative interest in Cicero as politician see G. Ianziti, “A New Life of Cicero”, in Id. 2011 (as in n. 7), 44-60.
} 
constitutional ideals, de facto best suited an aristocratic system, with elites determined by cultural as well as social and financial capital. Such a state had less in common with the broad franchise guaranteed by Florence's traditional guild republicanism than with the oligarchy that was republican Rome. The reintroduction of Ciceronian Latin as the political language would in and of itself make Florence more like Rome as a bilingual polity. In addition, it had the potential to transform her ruling classes, likewise in the image of the Roman Republic.

In this line of thinking, Ciceronianism is not only a linguistic, but also a political ideal. Ciceronian Latin would not merely be an ornament to Florence, but contribute to the republic's good government by the most qualified men - one of the qualifications being knowledge of Latin letters. This interpretation salvages some of Hans Baron's civic humanism, in that it shows why, from Bruni's perspective, Florence proffered the ideal conditions for a revival of Latin, and also why the humanist movement could genuinely contribute to Florentine politics. Yet at the same time, it has an advantage over Baron's reading in as much as, while the sincerity of Bruni's commitment to the existing Florentine communal government is indeed questionable, his cultural and political elitism cannot seriously be in doubt. With politics the preserve of the Latinate in Bruni's terms, literate - classes, Florence would be, just like Rome, a republican aristocracy, based on wealth, birth, but also eloquence. To conclude with the words of another student of language and politics: "The Revolution will be complete when the language is perfect."115

University of Exeter

h.schadee@exeter.ac.uk

${ }^{115}$ G. Orwell, Nineteen Eighty-Four (London, 1992), 55. 